NBER WORKING PAPER SERIES

TECHNOLOGY SHOCKS IN THE NEW KEYNESIAN MODEL

Peter N. Ireland

Working Paper 10309

http://www.nber.org/papers/w10309

NATIONAL BUREAU OF ECONOMIC RESEARCH

1050 Massachusetts Avenue

Cambridge, MA 02138

February 2004

The views expressed herein are those of the authors and not necessarily those of the National Bureau of Economic Research.

C2004 by Peter N. Ireland. All rights reserved. Short sections of text, not to exceed two paragraphs, may be quoted without explicit permission provided that full credit, including $(\mathrm{C}$ notice, is given to the source. 
Technology Shocks in the New Keynesian Model

Peter N. Ireland

NBER Working Paper No. 10309

February 2004

JEL No. E32

\section{$\underline{\text { ABSTRACT }}$}

In the New Keynesian model, preference, cost-push, and monetary shocks all compete with the real business cycle model's technology shock in driving aggregate fluctuations. A version of this model, estimated via maximum likelihood, points to these other shocks as being more important for explaining the behavior of output, inflation, and interest rates in the postwar United States data. These results weaken the links between the current generation of New Keynesian models and the real business cycle models from which they were originally derived. They also suggest that Federal Reserve officials have often faced difficult trade-offs in conducting monetary policy.

Peter N. Ireland

Boston College, Department of Economics

Administration Building

140 Commonwealth Ave.

Chestnut Hill, MA 02467-3806

and NBER

irelandp@bc.edu 


\title{
Technology Shocks in the New Keynesian Model
}

\author{
Peter N. Ireland* \\ Boston College and NBER
}

February 2004

\begin{abstract}
In the New Keynesian model, preference, cost-push, and monetary shocks all compete with the real business cycle model's technology shock in driving aggregate fluctuations. A version of this model, estimated via maximum likelihood, points to these other shocks as being more important for explaining the behavior of output, inflation, and interest rates in the postwar United States data. These results weaken the links between the current generation of New Keynesian models and the real business cycle models from which they were originally derived. They also suggest that Federal Reserve officials have often faced difficult trade-offs in conducting monetary policy. $J E L: \mathrm{E} 32$.
\end{abstract}

\section{Introduction}

The development of the forward-looking, microfounded, New Keynesian model stands, in the eyes of many observers, as one of the past decade's most exciting and significant achievements in macroeconomics. To cite just two especially prominent examples: Clarida, Gali, and Gertler (1999) place the New Keynesian model at center stage in their widely-read survey 
of recent research on monetary policy, while Woodford (2003) builds his comprehensive monograph around the same analytic foundations.

In its simplest form, the New Keynesian model consists of just three equations. The first, which Kerr and King (1996) and McCallum and Nelson (1999) call the expectational IS curve, corresponds to the log-linearization of an optimizing household's Euler equation, linking consumption and output growth to the inflation-adjusted return on nominal bonds, that is, to the real interest rate. The second, a forward-looking version of the Phillips curve, describes the optimizing behavior of monopolistically competitive firms that either set prices in a randomly staggered fashion, as suggested by Calvo (1983), or face explicit costs of nominal price adjustment, as suggested by Rotemberg (1982). The third and final equation, a monetary policy rule of the kind proposed by Taylor (1993), dictates that the central bank should adjust the short-term nominal interest rate in response to changes in output and, especially, inflation. The New Keynesian model brings these three equations together to characterize the dynamic behavior of three key macroeconomic variables: output, inflation, and the nominal interest rate.

Thus, the New Keynesian model places heavy emphasis on the behavior of nominal variables, calls special attention to the workings of monetary policy rules, and contains frequent allusions back to the traditional IS-LM framework. All this makes it easy to forget that the New Keynesian models of today share many basic features with, and indeed were originally derived as extensions to, a previous generation of dynamic, stochastic, general equilibrium models: the real business cycle models of Kydland and Prescott (1982), Long and Plosser (1983), King, Plosser, and Rebelo (1988), and many others. In real business cycle models, technology shocks play the dominant role in driving macroeconomic fluctuations. Monetary policy either remains absent, as in the three papers just cited, or has minimal effects on the cyclical behavior of the economy, as in Cooley and Hansen (1989).

Yet technology shocks also play a role in the New Keynesian model where, for instance, 
an increase in productivity lowers each firm's marginal costs and thereby feeds into its optimal pricing decisions. The New Keynesian model therefore retains the idea that technology shocks can be quite important in shaping the dynamic behavior of key macroeconomic variables. It merely refines and extends this idea by suggesting, first, that other shocks might be important as well and, second, that in any case the presence of nominal price rigidities helps determine exactly how shocks of all kinds impact on and propagate through the economy.

This paper re-exposes and further explores this link between the current generation of New Keynesian models and the previous generation of real business cycle models. More specifically, it examines, quantitatively and with the help of formal econometric methods, the importance of technology shocks within the New Keynesian framework.

Towards that end, section 2 of the paper develops a version of the New Keynesian model in which three additional disturbances - to households' preferences, to firms' desired markups, and to the central bank's monetary policy rule compete with the real business cycle model's technology shock in accounting for fluctuations in output, inflation, and interest rates. Since this New Keynesian model allows, but does not require, technology shocks to remain dominant as the primary source of business cycle fluctuations, it provides a useful framework in which the most basic, technology-driven, specification can be compared, statistically, to a more general and flexible alternative.

Section 3 of the paper then uses maximum likelihood, together with quarterly data from the postwar United States, to estimate the parameters of this more general New Keynesian model. There, a series of exercises conducted with the estimated model leads directly to the paper's main results on the role of technology shocks in the New Keynesian model. Section 4 concludes by summarizing those results and highlighting their implications. 


\section{The New Keynesian Model}

As explained above, this section develops a version of the New Keynesian model that will be used, later, for an econometric analysis of the relative importance of technology shocks in generating variability in the postwar United States data. The model economy consists of a representative household, a representative finished goods-producing firm, a continuum of intermediate goods-producing firms indexed by $i \in[0,1]$, and a central bank. During each period $t=0,1,2, \ldots$, each intermediate goods-producing firm produces a distinct, perishable intermediate good. Hence, intermediate goods may also be indexed by $i \in[0,1]$, where firm $i$ produces good $i$. The model features enough symmetry, however, to allow the analysis to focus on the activities of a representative intermediate goods-producing firm, identified by the generic index $i$. The behavior of each of these agents, together with their implications for the evolution of equilibrium prices and quantities, will now be described in turn.

\subsection{The Representative Household}

The representative household enters each period $t=0,1,2, \ldots$ with money $M_{t-1}$ and bonds $B_{t-1}$. At the beginning of the period, the household receives a lump-sum monetary transfer $T_{t}$ from the central bank. Next, the household's bonds mature, providing $B_{t-1}$ additional units of money. The household uses some of this money to purchase new bonds of value $B_{t} / r_{t}$, where $r_{t}$ denotes the gross nominal interest rate between $t$ and $t+1$.

During period $t$, the household supplies $h_{t}$ units of labor to the various intermediate goods-producing firms, earning $W_{t} h_{t}$ in total labor income, where $W_{t}$ denotes the nominal wage. The household also consumes $C_{t}$ units of the finished good, purchased at the nominal price $P_{t}$ from the representative finished goods-producing firm. Finally, at the end of period $t$, the household receives nominal profits $D_{t}$ from the intermediate goods-producing firms. 
It then carries $M_{t}$ units of money into period $t+1$, chosen subject to the budget constraint

$$
M_{t-1}+B_{t-1}+T_{t}+W_{t} h_{t}+D_{t} \geq P_{t} C_{t}+B_{t} / r_{t}+M_{t}
$$

for all $t=0,1,2, \ldots$

Faced with these budget constraints, the household acts to maximize the expected utility function

$$
E \sum_{t=0}^{\infty} \beta^{t}\left[a_{t} \ln \left(C_{t}\right)+\ln \left(M_{t} / P_{t}\right)-(1 / \eta) h_{t}^{\eta}\right],
$$

with $1>\beta>0$ and $\eta \geq 1$. In this utility function, the preference shock $a_{t}$ follows the autoregressive process

$$
\ln \left(a_{t}\right)=\rho_{a} \ln \left(a_{t-1}\right)+\varepsilon_{a t},
$$

with $1>\rho_{a} \geq 0$, where the zero-mean, serially uncorrelated innovation $\varepsilon_{a t}$ is normally distributed with standard deviation $\sigma_{a}$. Driscoll (2000) and Ireland (2002a) show that the additive separability of this utility function in its three arguments - consumption, real money balances, and hours worked - is needed to obtain a conventional specification for the model's IS curve that, in particular, excludes additional terms involving real balances and employment. Meanwhile, King, Plosser, and Rebelo (1988) show that given this additive separability, the logarithmic form for utility from consumption is needed for the model to be consistent with balanced growth.

The first-order conditions for the household's problem include the intratemporal optimality condition

$$
h_{t}^{\eta-1}=\left(a_{t} / C_{t}\right)\left(W_{t} / P_{t}\right)
$$

linking the real wage to the marginal rate of substitution between leisure and consumption, 
and the intertemporal optimality condition

$$
a_{t} / C_{t}=\beta r_{t} E_{t}\left[\left(a_{t+1} / C_{t+1}\right)\left(P_{t} / P_{t+1}\right)\right]
$$

linking the inflation-adjusted nominal interest rate - that is, the real interest rate - to the intertemporal marginal rate of substitution. The household's first-order conditions also include the budget constraint (1) with equality and an optimality condition for money holdings, which plays the role of the model's money demand relationship. Under an interest rate rule for monetary policy like the one introduced below, however, this money demand equation serves only to determine how much money the central bank needs to supply to clear markets given its interest rate target $r_{t}$. Hence, so long as the dynamic behavior of the money stock is not of independent interest, this equation can be dropped from consideration, together with all future reference to the variable $M_{t}$. Each of these optimality conditions must hold, of course, for all $t=0,1,2, \ldots$.

\subsection{The Representative Finished Goods-Producing Firm}

During each period $t=0,1,2, \ldots$, the representative finished goods-producing firm uses $Y_{t}(i)$ units of each intermediate good $i \in[0,1]$, purchased at the nominal price $P_{t}(i)$, to manufacture $Y_{t}$ units of the finished good according to the constant-returns-to-scale technology described by

$$
\left[\int_{0}^{1} Y_{t}(i)^{\left(\theta_{t}-1\right) / \theta_{t}} d i\right]^{\theta_{t} /\left(\theta_{t}-1\right)} \geq Y_{t}
$$

As shown below and in Smets and Wouters (2003) and Steinsson (2003), $\theta_{t}$ measures the time-varying elasticity of demand for each intermediate good; hence, it acts as a markup, or cost-push, shock of the kind introduced into the New Keynesian model by Clarida, Gali, 
and Gertler (1999). Here, this cost-push shock follows the autoregressive process

$$
\ln \left(\theta_{t}\right)=\left(1-\rho_{\theta}\right) \ln (\theta)+\rho_{\theta} \ln \left(\theta_{t-1}\right)+\varepsilon_{\theta t},
$$

with $\theta>1$ and $1>\rho_{\theta} \geq 0$, where the zero-mean, serially uncorrelated innovation $\varepsilon_{\theta t}$ is normally distributed with standard deviation $\sigma_{\theta}$.

The finished goods-producing firm maximizes its profits by choosing

$$
Y_{t}(i)=\left[P_{t}(i) / P_{t}\right]^{-\theta_{t}} Y_{t}
$$

for all $i \in[0,1]$ and $t=0,1,2, \ldots$, which confirms that $\theta_{t}$ measures the time-varying elasticity of demand for each intermediate good. Competition drives the finished goods-producing firm's profits to zero in equilibrium, determining $P_{t}$ as

$$
P_{t}=\left[\int_{0}^{1} P_{t}(i)^{1-\theta_{t}} d i\right]^{1 /\left(1-\theta_{t}\right)}
$$

for all $t=0,1,2, \ldots$

\subsection{The Representative Intermediate Goods-Producing Firm}

During each period $t=0,1,2, \ldots$, the representative intermediate goods-producing firm hires $h_{t}(i)$ units of labor from the representative household to manufacture $Y_{t}(i)$ units of intermediate good $i$ according to the constant-returns-to-scale technology described by

$$
Z_{t} h_{t}(i) \geq Y_{t}(i)
$$


Here, as in many versions of the real business cycle model, the aggregate technology shock $Z_{t}$ follows a random walk with positive drift:

$$
\ln \left(Z_{t}\right)=\ln (z)+\ln \left(Z_{t-1}\right)+\varepsilon_{z t},
$$

with $z>1$, where the zero-mean, serially uncorrelated innovation $\varepsilon_{z t}$ is normally distributed with standard deviation $\sigma_{z}$.

Since the intermediate goods substitute imperfectly for one another in producing the finished good, the representative intermediate goods-producing firm sells its output in a monopolistically competitive market: during period $t$, the intermediate goods-producing firm sets the price $P_{t}(i)$ for its output, subject to the requirement that it satisfy the finished goods-producing firm's demand at its chosen price. In addition, the intermediate goodsproducing firm faces an explicit cost of nominal price adjustment, measured in terms of the finished good and given by

$$
\frac{\phi}{2}\left[\frac{P_{t}(i)}{\pi P_{t-1}(i)}-1\right]^{2} Y_{t},
$$

where $\phi \geq 0$ governs the magnitude of the price adjustment cost and $\pi \geq 1$ measures the gross steady-state rate of inflation.

This quadratic cost of nominal price adjustment, first proposed by Rotemberg (1982), makes the intermediate goods-producing firm's problem dynamic. In particular, the firm must choose a sequence for $P_{t}(i)$ to maximize its total market value, given by

$$
E \sum_{t=0}^{\infty} \beta^{t}\left(a_{t} / C_{t}\right)\left[D_{t}(i) / P_{t}\right]
$$

where $\beta^{t}\left(a_{t} / C_{t}\right)$ measures the marginal utility value to the representative household of an 
additional unit of real profits generated during period $t$ and where

$$
\frac{D_{t}(i)}{P_{t}}=\left[\frac{P_{t}(i)}{P_{t}}\right]^{1-\theta_{t}} Y_{t}-\left[\frac{P_{t}(i)}{P_{t}}\right]^{-\theta_{t}}\left(\frac{W_{t}}{P_{t}}\right)\left(\frac{Y_{t}}{Z_{t}}\right)-\frac{\phi}{2}\left[\frac{P_{t}(i)}{\pi P_{t-1}(i)}-1\right]^{2} Y_{t}
$$

measures real profits, incorporating the linear production function from (6) as well as the requirement that the firm produce and sell output on demand at its chosen price $P_{t}(i)$ during each period $t=0,1,2, \ldots$. The first-order conditions for this problem are

$$
\begin{aligned}
& \left(\theta_{t}-1\right)\left[\frac{P_{t}(i)}{P_{t}}\right]^{-\theta_{t}}\left(\frac{Y_{t}}{P_{t}}\right) \\
= & \theta_{t}\left[\frac{P_{t}(i)}{P_{t}}\right]^{-\theta_{t}-1}\left(\frac{W_{t}}{P_{t}}\right)\left(\frac{Y_{t}}{Z_{t}}\right)\left(\frac{1}{P_{t}}\right)-\phi\left[\frac{P_{t}(i)}{\pi P_{t-1}(i)}-1\right]\left[\frac{Y_{t}}{\pi P_{t-1}(i)}\right] \\
& +\beta \phi E_{t}\left\{\left(\frac{a_{t+1}}{a_{t}}\right)\left(\frac{C_{t}}{C_{t+1}}\right)\left[\frac{P_{t+1}(i)}{\pi P_{t}(i)}-1\right]\left[\frac{Y_{t+1}}{P_{t}(i)}\right]\left[\frac{P_{t+1}(i)}{\pi P_{t}(i)}\right]\right\}
\end{aligned}
$$

for all $t=0,1,2, \ldots$. In the special case where $\phi=0,(9)$ collapses to

$$
P_{t}(i)=\left[\theta_{t} /\left(\theta_{t}-1\right)\right]\left(W_{t} / Z_{t}\right)
$$

indicating that in the absence of costly price adjustment, the intermediate goods-producing firm sets its markup of price $P_{t}(i)$ over marginal cost $W_{t} / Z_{t}$ equal to $\theta_{t} /\left(\theta_{t}-1\right)$ where, again, $\theta_{t}$ measures the price elasticity of demand for its output. Thus, more generally, $\theta_{t}$ can be interpreted as a shock to the firm's desired markup; with costly price adjustment, the firm's actual markup will differ from, but tend to gravitate towards, the desired markup over time.

\subsection{Symmetric Equilibrium}

In a symmetric equilibrium, all intermediate goods-producing firms make identical decisions, so that $Y_{t}(i)=Y_{t}, h_{t}(i)=h_{t}, P_{t}(i)=P_{t}$, and $D_{t}(i)=D_{t}$ for all $i \in[0,1]$ and $t=0,1,2, \ldots$ In addition, the market-clearing conditions $M_{t}=M_{t-1}+T_{t}$ and $B_{t}=B_{t-1}=0$ must hold for 
all $t=0,1,2, \ldots$. With these equilibrium conditions imposed, (3), (6), and (8) can be used to solve out for the real wage $W_{t} / P_{t}$, hours worked $h_{t}$, and real profits $D_{t} / P_{t}$. The representative household's budget constraint (1) can then be rewritten as the aggregate resource constraint

$$
Y_{t}=C_{t}+\frac{\phi}{2}\left(\frac{\pi_{t}}{\pi}-1\right)^{2} Y_{t}
$$

the household's Euler equation (4) can be rewritten as

$$
a_{t} / C_{t}=\beta r_{t} E_{t}\left[\left(a_{t+1} / C_{t+1}\right)\left(1 / \pi_{t+1}\right)\right]
$$

and the representative intermediate goods-producing firm's first-order condition (9) can be rewritten as

$$
\begin{aligned}
\theta_{t}-1= & \theta_{t}\left(\frac{C_{t}}{a_{t}}\right)\left(\frac{Y_{t}}{Z_{t}}\right)^{\eta-1}\left(\frac{1}{Z_{t}}\right)-\phi\left(\frac{\pi_{t}}{\pi}-1\right)\left(\frac{\pi_{t}}{\pi}\right) \\
& +\beta \phi E_{t}\left[\left(\frac{a_{t+1}}{a_{t}}\right)\left(\frac{C_{t}}{C_{t+1}}\right)\left(\frac{\pi_{t+1}}{\pi}-1\right)\left(\frac{\pi_{t+1}}{\pi}\right)\left(\frac{Y_{t+1}}{Y_{t}}\right)\right]
\end{aligned}
$$

where $\pi_{t}=P_{t} / P_{t-1}$ denotes the gross inflation rate for all $t=0,1,2, \ldots$.

\subsection{Efficient Allocations and the Output Gap}

As a first step in interpreting the model's equilibrium conditions, consider the problem faced by a social planner who can overcome the frictions that cause real money balances to show up in the representative household's utility function and that give rise to the cost of nominal price adjustment facing the representative intermediate goods-producing firm. During each period $t=0,1,2, \ldots$, this social planner allocates $n_{t}(i)$ units of the representative household's labor to produce $Q_{t}(i)$ units of each intermediate good $i \in[0,1]$, then uses those various

intermediate goods to produce $Q_{t}$ units of the finished good, all according to the same 
constant-returns-to-scale technologies described above.

Thus, the social planner chooses $Q_{t}$ and $n_{t}(i)$ for all $i \in[0,1]$ and $t=0,1,2, \ldots$ to maximize the household's welfare, as measured by

$$
E \sum_{t=0}^{\infty} \beta^{t}\left\{a_{t} \ln \left(Q_{t}\right)-(1 / \eta)\left[\int_{0}^{1} n_{t}(i) d i\right]^{\eta}\right\}
$$

subject to the feasibility constraints

$$
Z_{t}\left[\int_{0}^{1} n_{t}(i)^{\left(\theta_{t}-1\right) / \theta_{t}} d i\right]^{\theta_{t} /\left(\theta_{t}-1\right)} \geq Q_{t}
$$

for all $t=0,1,2, \ldots$. The first-order conditions to this problem define the efficient level of output $Q_{t}$ as

$$
Q_{t}=a_{t}^{1 / \eta} Z_{t}
$$

for all $t=0,1,2, \ldots$. According to this definition, the efficient level of output increases after a favorable preference shock $a_{t}$ or technology shock $Z_{t}$. By contrast, the efficient level of output does not depend on the realization of the cost-push shock $\theta_{t}$. The model's output gap $x_{t}$, defined as the ratio between the actual and efficient levels of output, can therefore be calculated as

$$
x_{t}=\left(1 / a_{t}\right)^{1 / \eta}\left(Y_{t} / Z_{t}\right)
$$

for all $t=0,1,2, \ldots$

\subsection{The Linearized Model}

Equations (2), (5), (7), and (10)-(13) describe the behavior of the five endogenous variables $Y_{t}, C_{t}, \pi_{t}, r_{t}$, and $x_{t}$ and the three exogenous shocks $a_{t}, \theta_{t}$, and $Z_{t}$. These equations imply that in equilibrium, output $Y_{t}$ and consumption $C_{t}$ both inherit a unit root from the process 
(7) for the technology shock $Z_{t}$. On the other hand, the stochastically detrended variables $y_{t}=Y_{t} / Z_{t}, c_{t}=C_{t} / Z_{t}$, and $z_{t}=Z_{t} / Z_{t-1}$ remain stationary, as do the output gap $x_{t}$ and the growth rate of output $g_{t}$, defined as

$$
g_{t}=Y_{t} / Y_{t-1}
$$

for all $t=0,1,2, \ldots$

These equations also imply that in the absence of shocks, the economy converges to a steady-state growth path, along which all of the stationary variables are constant over time, with $y_{t}=y, c_{t}=c, \pi_{t}=\pi, r_{t}=r, x_{t}=x, g_{t}=g, a_{t}=1, \theta_{t}=\theta$, and $z_{t}=z$ for all $t=0,1,2, \ldots$ Accordingly, let $\hat{y}_{t}=\ln \left(y_{t} / y\right), \hat{c}_{t}=\ln \left(c_{t} / c\right), \hat{\pi}_{t}=\ln \left(\pi_{t} / \pi\right), \hat{r}_{t}=\ln \left(r_{t} / r\right)$, $\hat{x}_{t}=\ln \left(x_{t} / x\right), \hat{g}_{t}=\ln \left(g_{t} / g\right), \hat{a}_{t}=\ln \left(a_{t}\right), \hat{\theta}_{t}=\ln \left(\theta_{t} / \theta\right)$, and $\hat{z}_{t}=\ln \left(z_{t} / z\right)$ denote the percentage deviation of each variable from its steady-state level. In a log-linearized version of the model, the resource constraint (10) implies that $\hat{c}_{t}=\hat{y}_{t}$, while (2), (5), (7), and (11)-(14) become

$$
\begin{gathered}
\hat{a}_{t}=\rho_{a} \hat{a}_{t-1}+\varepsilon_{a t}, \\
\hat{e}_{t}=\rho_{e} \hat{e}_{t-1}+\varepsilon_{e t}, \\
\hat{z}_{t}=\varepsilon_{z t}, \\
\hat{x}_{t}=E_{t} \hat{x}_{t+1}-\left(\hat{r}_{t}-E_{t} \hat{\pi}_{t+1}\right)+(1-\omega)\left(1-\rho_{a}\right) \hat{a}_{t}, \\
\hat{\pi}_{t}=\beta E_{t} \hat{\pi}_{t+1}+\psi \hat{x}_{t}-\hat{e}_{t}, \\
\hat{x}_{t}=\hat{y}_{t}-\omega \hat{a}_{t},
\end{gathered}
$$

and

$$
\hat{g}_{t}=\hat{y}_{t}-\hat{y}_{t-1}+\hat{z}_{t}
$$


for all $t=0,1,2, \ldots$. To assist in the econometric analysis of these equations, the new parameter $\omega$ in (18) and (20) has been defined as $\omega=1 / \eta$ and the new parameter $\psi$ in (19) has been defined as $\psi=\eta(\theta-1) / \phi$. The transformed cost-push shock $\hat{e}_{t}$ in (19) has been defined as $(1 / \phi) \hat{\theta}_{t}$, so that in (16), $\rho_{e}=\rho_{\theta}$ and the zero-mean, serially uncorrelated innovation $\varepsilon_{e t}$ is normally distributed with standard deviation $\sigma_{e}=(1 / \phi) \sigma_{\theta}$.

In this linear system, (15)-(17) govern the behavior of the preference, cost-push, and technology shocks $\hat{a}_{t}, \hat{\theta}_{t}$, and $\hat{z}_{t}$, while (20) and (21) serve to define the output gap $\hat{x}_{t}$ and the growth rate of output $\hat{g}_{t}$. Equation (18) takes the form of the expectational IS curve, and (19) is a version of the New Keynesian Phillips curve. Note that although the preference and technology shocks $\hat{a}_{t}$ and $\hat{z}_{t}$ do not appear explicitly in the model's Phillips curve, both enter implicitly through the definition of the output gap $\hat{x}_{t} \cdot{ }^{1}$ More traditional analyses of the Phillips curve, such as Ball and Mankiw's (2002), typically draw a distinction between shocks that affect the natural rate of unemployment and shocks that do not. Here, by analogy, (19) draws a distinction between the shocks $\hat{a}_{t}$ and $\hat{z}_{t}$ that impact on the efficient level of output and the shock $\hat{e}_{t}$ that does not.

Note, too, that in the absence of the cost-push shock $\hat{e}_{t}$, the IS and Phillips curves (18) and (19) imply that the central bank can stabilize both the inflation rate and the output gap by adopting a monetary policy that allows the real market rate of interest $\hat{r}_{t}-E_{t} \hat{\pi}_{t+1}$ to track the natural rate of interest, defined as $(1-\omega)\left(1-\rho_{a}\right) \hat{a}_{t}$. As emphasized by Clarida, Gali and Gertler (1999), Gali (2002), and Woodford (2003), only the cost-push shock confronts the central bank with a trade-off between inflation and output gap stabilization as competing goals of monetary policy. 


\subsection{The Central Bank}

The central bank conducts monetary policy by following the modified Taylor (1993) rule

$$
\hat{r}_{t}-\hat{r}_{t-1}=\rho_{\pi} \hat{\pi}_{t}+\rho_{g} \hat{g}_{t}+\rho_{x} \hat{x}_{t}+\varepsilon_{r t},
$$

according to which it raises or lowers the short-term nominal interest rate $\hat{r}_{t}$ in response to deviations of inflation $\hat{\pi}_{t}$, output growth $\hat{g}_{t}$, and the output gap $\hat{x}_{t}$ from their steadystate levels. When adopting a rule of this form, the central bank takes responsibility for choosing the steady-state inflation rate $\pi$; it also chooses the response parameters $\rho_{\pi}, \rho_{g}$, and $\rho_{x}$. In particular, a positive response of the interest rate to movements in inflation, as measured by $\rho_{\pi}$, insures that this policy rule remains consistent with the existence of a unique rational expectations equilibrium; for details, see Parkin (1978), McCallum (1981), Fuhrer and Moore (1995), Kerr and King (1996), and Clarida, Gali, and Gertler (2000). ${ }^{2}$ Since it is unclear whether it is more appropriate to depict the central bank as responding to movements in output growth - a variable that it can observe directly - or movements in the output gap - a variable that is more closely related to the representative household's welfare - both measures of real economic activity appear in this interest rate rule. Finally, in (22), the zero-mean, serially uncorrelated innovation $\varepsilon_{r t}$ is normally distributed with standard deviation $\sigma_{r}$.

\section{Econometric Strategy and Results}

Equations (15)-(22) now form a system involving three observable variables - output growth $\hat{g}_{t}$, inflation $\hat{\pi}_{t}$, and the short-term nominal interest rate $\hat{r}_{t}$ - two unobservable variablesstochastically detrended output $\hat{y}_{t}$ and the output gap $\hat{x}_{t}$ - and four unobservable shocks - to preferences $\hat{a}_{t}$, desired markups $\hat{e}_{t}$, technology $\hat{z}_{t}$, and monetary policy $\varepsilon_{r t}$. The solution to 
this system, derived using Klein's (2000) modification of the Blanchard-Kahn (1980) procedure, takes the form of a state-space econometric model. Hence, the Kalman filtering algorithms outlined by Hamilton (1994, Ch.13) can be applied to estimate the model's parameters via maximum likelihood and to draw inferences about the behavior of the model's unobservable components based on the information contained in the three observable series.

Here, this econometric exercise uses quarterly United States data running from 1948:1 through 2003:1. In these data, quarterly changes in seasonally-adjusted figures for real GDP, converted to per-capita terms by dividing by the civilian noninstitutional population, age 16 and over, serve to measure output growth. Quarterly changes in the seasonally adjusted GDP deflator yield the measure of inflation, and quarterly averages of daily readings on the three-month US Treasury bill rate provide the measure of the nominal interest rate.

This econometric exercise has as its principal goal, of course, the objective of measuring the contributions made by the various shocks in driving fluctuations in the model's observable and unobservable variables. With this goal in mind, the empirical strategy followed here begins by adding lagged output gap and inflation terms to the model's IS and Phillips curves, so that (18) and (19) are replaced by

$$
\hat{x}_{t}=\alpha_{x} \hat{x}_{t-1}+\left(1-\alpha_{x}\right) E_{t} \hat{x}_{t+1}-\left(\hat{r}_{t}-E_{t} \hat{\pi}_{t+1}\right)+(1-\omega)\left(1-\rho_{a}\right) \hat{a}_{t}
$$

and

$$
\hat{\pi}_{t}=\beta\left[\alpha_{\pi} \hat{\pi}_{t-1}+\left(1-\alpha_{\pi}\right) E_{t} \hat{\pi}_{t+1}\right]+\psi \hat{x}_{t}-\hat{e}_{t}
$$

for all $t=0,1,2, \ldots$. These modifications serve to guard against the possibility that estimates of the purely forward-looking specification might falsely attribute dynamics found in the data to serial correlation in the shocks when instead those dynamics are more accurately modelled as the product of additional frictions - not explicitly considered here - that give 
rise to backward-looking behavior on the part of households and firms. The new parameters $\alpha_{x}$ and $\alpha_{\pi}$ in (23) and (24) both lie between zero and one; conveniently, they summarize the importance of backward-looking elements in the economy. And if, in fact, the data do prefer the original microfounded specifications (18) and (19) to the more general alternatives (23) and (24), the estimation procedure remains free to select values of $\alpha_{x}$ and $\alpha_{\pi}$ equal to zero.

The empirical model consisting of (15)-(17) and (21)-(24) has 16 parameters: $z, \pi, \beta, \omega$, $\psi, \alpha_{x}, \alpha_{\pi}, \rho_{\pi}, \rho_{g}, \rho_{x}, \rho_{a}, \rho_{e}, \sigma_{a}, \sigma_{e}, \sigma_{z}$, and $\sigma_{r}$. Among these parameters, $z$ and $\pi$ serve only to pin down the steady-state values of output growth and inflation; they have no impact on the model's dynamics. Hence, prior to estimating the remaining parameters, $z$ is set equal to 1.0048 , matching the average growth rate of per-capita output in the data, which equals 1.95 percent on an annualized basis. Likewise, $\pi$ is set equal to 1.0086 , matching the average inflation rate in the data, which equals 3.48 percent when annualized.

A problem then arises, because according to the model, the steady-state nominal interest rate is determined as $r=\pi(z / \beta)$. Given the settings for $z$ and $\pi$, the model requires a value of the representative household's discount factor $\beta$ that exceeds its upper bound of unity to match the average nominal interest rate in the data, which equals 5.09 percent when annualized. Fundamentally, of course, this problem stems from Weil's (1989) "riskfree rate puzzle," according to which representative agent models like the one used here systematically overpredict the historical returns on US Treasury bills. To help resolve this difficulty, the model's restrictions are loosened slightly: the parameter $\beta$ is simply set equal to 0.99 , implying an annual discount rate of 4 percent, and the steady-state nominal interest rate is treated as an additional parameter that is then set to match the average nominal interest rate in the data. ${ }^{3}$ In effect, this procedure allows the series for output growth, inflation, and the interest rate to be accurately demeaned before using them for maximum likelihood estimation. Again, this approach guards against the possibility that otherwise, the estimated model will attempt to account for systematic deviations of the observed variables 
from their steady-state levels by overstating the persistence of the exogenous shocks.

Preliminary attempts to implement the maximum likelihood procedure led consistently to unreasonably small estimates of $\psi$, the coefficient on the output gap in the Phillips curve (24). Since, as noted above, $\psi$ depends inversely on the price adjustment cost parameter $\phi$, these very small estimates of $\psi$ translate into very large costs of nominal price adjustment. Hence, in deriving the final set of results, this parameter is also fixed prior to estimation at $\psi=0.1$, the same value used previously in Ireland (2000, 2002a). The formulas displayed in Gali and Gertler (1999) provide a convenient way of interpreting this parameter setting: they imply that in a simpler version of the New Keynesian model in which price setting is staggered according to Calvo's (1983) specification and in which utility is linear in hours worked so that the output gap always moves in lockstep with firms' real marginal costs, a value of $\psi=0.1$ corresponds to the case where individual goods prices are reset on average every 3.74 quarters - or just a little more frequently than once per year.

And so, with $z, \pi, \beta$, and $\psi$ held fixed, table 1 displays the maximum likelihood estimates of the remaining 12 parameters together with their standard errors, computed by taking the square roots of the diagonal elements of minus one times the inverted matrix of second derivatives of the maximized log-likelihood function. Looking first at the individual parameters, the point estimate of $\omega=0.0617$ is small and lies within one standard error of zero. Since $\omega=1 / \eta$ by definition, this small estimate of $\omega$ translates into a very large estimate of $\eta$-and hence a very inelastic labor supply schedule in the theoretical model. In the empirical model with $\psi=\eta(\theta-1) / \phi=0.1$ held fixed, however, $\omega$ serves mainly to determine, via (20), the extent to which the preference shock $\hat{a}_{t}$ impacts on the efficient level of output $Q_{t}$ and hence on the output gap $\hat{x}_{t}$. The small estimate of $\omega$, therefore, simply implies that the data prefer a version of the model in which the efficient level of output remains largely unaffected by the preference shock. The estimate of $\alpha_{x}=0.0836$ is also quite small and statistically insignificant, and the estimate of $\alpha_{\pi}$ lies up against its lower 
bound of zero, providing evidence in support of the purely forward-looking versions of the IS and Phillips curves. These results echo those reported previously in Ireland (2001), a study that focuses more specifically on the importance of backward-looking elements in the New Keynesian Phillips curve.

The large and significant estimates of $\rho_{\pi}=0.3597$ and $\rho_{g}=0.2536$ suggest that historically, Federal Reserve policy has responded strongly to movements in both inflation and output growth; the much smaller estimate of $\rho_{x}=0.0347$ indicates that the welfare-theoretic output gap as defined by the New Keynesian model has played less of a role in the policymaking process. The estimates of $\rho_{a}=0.9470$ and $\rho_{e}=0.9625$ imply that, like the model's technology shock, the preference and cost-push shocks are highly persistent. Finally, the estimates of $\sigma_{a}=0.0405, \sigma_{e}=0.0012, \sigma_{z}=0.0109$, and $\sigma_{r}=0.0031$ all appear large compared to their standard errors, suggesting that all four shocks contribute in some way towards explaining movements in the data. And, interestingly, the estimate of $\sigma_{z}=0.0109$ for the standard deviation of the innovation to the technology shock is of the same order of magnitude as the calibrated values assigned to this parameter in Kydland and Prescott (1982), Cooley and Hansen (1989), and other real business cycle studies.

Thus, the individual parameter estimates shown in table 1 suggest that while the real business cycle model's technology shock continues to play a role in the New Keynesian model, the competing shocks - to preferences, desired markups, and monetary policy - take on some importance as well. To dig deeper into these issues, figure 1 plots the impulse responses of output, inflation, the nominal interest rate, and the output gap to each of these four shocks.

The graphs show that after a one-standard-deviation preference shock, output growth rises by slightly more than 50 basis points - that is, one-half of one percentage point - and the annualized rate of inflation increases by about 28 basis points. Under the estimated policy rule, these movements in output growth and inflation push the short-term nominal interest rate up by 65 basis points and, in fact, hold the short-term rate well above its 
steady-state level for more than four years after the shock. The output gap increases as well.

Meanwhile, a one-standard-deviation cost-push shock increases output growth by 25 basis points and reduces the annualized inflation rate by 140 basis points. The fall in inflation allows for an easing of monetary policy under which the short-term nominal interest rate falls by about 30 basis points and, again, remains well away from its steady-state level for more than four years. Since, as noted above, the cost-push shock leaves the efficient level of output unchanged, the increase in the equilibrium level of output leads to a sizeable rise in the output gap, which is amplified and propagated by the systematic monetary easing.

A one-standard-deviation technology shock increases output growth by 53 basis points and lowers the annualized inflation rate by about 75 basis points; on balance, these changes generate a small increase in the short-term nominal interest rate. And since the efficient level of output responds strongly to the technology shock, the output gap falls even as output growth rises in this case.

Finally, the estimated monetary policy shock translates into an exogenous 21-basis-point increase in the short-term nominal interest rate, which dies off over a period of about two years. This monetary tightening causes output growth to fall by 63 basis points and inflation to fall by 83 basic points; the output gap falls sharply as well.

Looking across all of these impulse responses provides some insight into how the various shocks are identified in the estimated New Keynesian model. The preference shock and the monetary policy shock, for instance, both work to increase the nominal interest rate. But in the case of the preference shock, this rise in the interest rate coincides with faster rates of output growth and inflation, whereas after the monetary policy shock, output growth and inflation both fall. Likewise, the cost-push shock and the technology shock both work to increase the rate of output growth and lower the rate of inflation, but the cost-push shock leads to a decline in the nominal interest rate and opens up a positive output gap while the technology shock generates a rise in the nominal interest rate and produces a negative 
output gap. Furthermore, according to (5) and (7), only the technology shock can impact permanently on the level of output. Hence, in figure 1, the positive response of output growth that follows immediately from a favorable cost-push shock must be offset later by a sustained period of slightly below-average output growth, whereas the positive response of output growth that follows a favorable technology shock is never reversed.

Looking across all of these results also suggests that the technology shock plays, at most, a supporting role in this estimated New Keynesian model. Instead, in figure 1, the monetary policy shock generates the largest movements in output growth, the cost-push shock drives the largest changes in inflation, and the preference shock gives rise to the largest responses in the short-term nominal interest rate. Table 2 confirms these findings by decomposing the forecast error variances in output growth, inflation, the short-term nominal interest rate, and the output gap into components attributable to each of the four shocks.

The results of these variance decompositions show that technology shocks make their largest contribution in explaining movements in output growth, accounting for about 25 percent of the fluctuations in that variable across all forecast horizons. Even for output growth, however, the preference shocks contribute nearly the same amount - 20 to 25 percent — and the monetary policy shocks account for considerably more - almost 40 percent. Moreover, consistent with the impulse response analysis, the variance decompositions reveal that the cost-push shock dominates in explaining movements in inflation and the output gap, while the preference shock is most important in driving movements in the nominal interest rate.

Uniformly, then, these results point to the same conclusion: in the estimated New Keynesian model, the preference, cost-push, and monetary policy shocks all appear to be more important than the technology shock in explaining the dynamic behavior of key macroeconomic variables. But are these findings robust? Clarida, Gali, and Gertler (2000) formalize the idea that the monetary policies adopted by Federal Reserve Chairmen Volcker and Greenspan differ from those pursued by their predecessors by showing that the coefficients 
of an estimated Taylor (1993) rule shift when the sample is split around 1980. Moreover, Kim and Nelson (1999), McConnell and Perez-Quiros (2000), and Stock and Watson (2003) find that a shift in the time-series properties of real GDP occurs at roughly the same point in the United States data, raising the possibility that different sets of shocks hit the American economy before and after 1980. Table 3, therefore, presents the results of one check for robustness by showing what happens when the model is reestimated with data from two disjoint subsamples: the first running from 1948:1 through 1979:4 and the second running from 1980:1 through 2003:1.

In table 3 , the estimated policy coefficients $\rho_{\pi}, \rho_{g}, \rho_{x}$ do shift across subsamples, consistent with Clarida, Gali, and Gertler's (2000) findings. Here, in particular, Federal Reserve policy appears to have become more responsive to movements in all three variables - inflation, output growth, and the output gap - during the post-1980 period. Moreover, evidence of instability appears for other parameters as well. Most notably, the estimate of $\alpha_{x}=0.2028$ is significantly different from zero for the pre-1980 period, suggesting that backward-looking behavior on the part of consumers is more important in explaining the data from the earlier subsample. In addition, the cost-push shocks become considerably smaller but considerably more persistent moving from the first subsample to the second.

Figure 2 displays impulse responses generated from the model as estimated with pre1980 data; similarly, table 4 repeats the forecast error variance decompositions for that earlier subsample. The results of these exercises fit nicely with less formal accounts of postwar United States economic history. In particular, the variance decompositions reveal that for the pre-1980 period, monetary policy shocks assume an even greater importance in generating fluctuations in output growth; and while the cost-push shock continues to explain a large fraction of the movements in inflation, the monetary policy shock emerges as an equally significant driving force for that variable as well. Meanwhile, the impulse response of the interest rate to a pre-1980 monetary shock traces out a stylized pattern of 
"stop-go" policy, according to which an initial tightening is quickly reversed, presumably in an attempt to partially offset the negative effects on output. For the pre-1980 period, therefore, these results point to monetary policy as a major destabilizing influence on the United States economy; and even more so than in the full sample, technology shocks play a subsidiary role.

The post-1980 results shown in figure 3 and table 5 , on the other hand, display some differences. There, monetary policy contributes less to macroeconomic instability and the technology shock becomes more important in driving movements in output growth. These results, too, display some coherence with popular accounts that attribute the superior performance of the United States economy during the 1990s to improved monetary policymaking coupled with unexpected gains in productivity of exactly the type captured by the real business cycle model's technology shock. ${ }^{4}$ Nevertheless, even in table 5 where the technology shock appears most important, it still explains less than half of the variation in output growth across all forecast horizons. And, once again, cost-push and preference shocks explain most of the action in inflation and the nominal interest rate.

\section{Conclusions and Implications}

This paper develops a New Keynesian model in which three additional disturbances - to households' preferences, to firms' desired markups, and to the central bank's monetary policy rule compete with the real business cycle model's technology shock in driving aggregate fluctuations. It then applies maximum likelihood to estimate the parameters of this New Keynesian model and uses the estimated model to assess the relative importance of these various shocks in accounting for the dynamic behavior of output growth, inflation, and interest rates as seen in the postwar United States data.

The empirical results, described in detail above, point to monetary policy shocks as a ma- 
jor source of instability in output growth, particularly in the period before 1980. Meanwhile, the markup, or cost-push, shock emerges as the most important contributor to movements in inflation, and the preference shock is identified as the principal factor behind movements in the short-term nominal interest rate. Throughout, the technology shock plays only a modest role. Even during the post-1980 period, where they appear most important, technology shocks account for less than half of the observed variability in output growth and an even smaller fraction of the variation in inflation and interest rates. Overall, these results serve to weaken the links between the New Keynesian models of today and the real business cycle models from which they were originally derived. ${ }^{5}$

Long and Plosser (1983) emphasize one of the most striking implications of real business cycle models: to the extent that aggregate fluctuations are driven by technology shocks, those fluctuations are actually preferred by private agents and should not be offset by active stabilization policies. The results obtained here suggest that, by contrast, American households would have most likely preferred a more stable path for the United States economy than the one that was actually observed. On the other hand, the results derived here have a monetarist flavor as well, suggesting that significant improvements might have been achieved simply by removing monetary policy as an independent source of instability - again, especially during the years before 1980 .

Finally, Clarida, Gali, and Gertler (1999), Gali (2002), and Woodford (2003) also work with New Keynesian models that feature both technology and cost-push shocks. These studies show that for monetary policymakers, only the cost-push shock generates a painful trade-off between stabilizing the inflation rate and stabilizing a welfare-theoretic measure of the output gap; in the face of technology shocks alone, then tension between these two goals disappears. By highlighting the role of cost-push shocks in explaining the United States data, therefore, the empirical results obtained here also suggest that Federal Reserve policymakers have, in fact, faced difficult trade-offs throughout the postwar period. 
Of course, these results admit alternative interpretations. One could argue, for instance, that the basic New Keynesian model used here ignores capital accumulation, an important process through which technology shocks are propagated in most real business cycle models; and, to be sure, extending the analysis performed here to account for the effects of capital accumulation remains an important task for future research. Furthermore, one could also argue that the additional shocks introduced here actually work, within the econometric model, to soak up specification error in the microfounded, New Keynesian model. Even under this last, more pessimistic, interpretation, however, the ultimate conclusions remain much the same: presumably, one would still be led towards other specifications that go even farther beyond the original, real business cycle model.

\section{Footnotes}

*Please address correspondence to: Peter N. Ireland, Boston College, Department of Economics, 140 Commonwealth Avenue, Chestnut Hill, MA 02467-3859. Tel: (617) 5523687. Fax: (617) 552-2308. Email: irelandp@bc.edu. I would like to thank Miles Kimball, Julio Rotemberg, and two referees, along with conference and seminar participants at the Federal Reserve Board, the National Bureau of Economic Research, the University of Kansas, and the University of Quebec at Montreal, for very helpful comments and suggestions. This material is based upon work supported by the National Science Foundation under Grant No. SES-0213461. Any opinions, findings, and conclusions or recommendations expressed herein are my own and do not necessarily reflect the views of the National Bureau of Economic Research or the National Science Foundation. All data and programs used in this research are available at http://www2.bc.edu/ irelandp.

${ }^{1}$ In addition, the technology shock would appear together with the preference shock in 
the model's IS curve (18) were it not for the fact that here, technology is assumed to follow a pure random walk. See the earlier version of this paper, Ireland (2002b), for an alternative implementation of the same exercise conducted here, but where the technology shock follows a stationary autoregressive process instead.

${ }^{2}$ Fuhrer and Moore (1995), in particular, also use an interest rate that is specified in terms of the first-differenced interest rate; they provide a detailed explanation of how a rule of this form supports a unique equilibrium in which the interest rate is stationary in levels.

${ }^{3} \mathrm{Of}$ course, an alternative solution to this problem could be found by allowing for a departure from the logarithmic form of the representative household's preferences over consumption. As indicated above, however, this logarithmic form is essential if the model is to be consistent with balanced growth.

${ }^{4}$ Also, Gali, Lopez-Salido, and Valles (2003) present related results: their study uses a more conventional identified vector autoregression to show that post-1980 improvements in US monetary policy include changes that have allowed the economy to respond more efficiently to technology shocks.

${ }^{5}$ Accordingly, this paper joins several others from the recent literature, including Basu, Fernald, and Kimball (1998), Gali (1999), and Francis and Ramey (2003), which take a variety of different empirical approaches to distinguish between the real business cycle and New Keynesian models and to argue against the importance of technology shocks as a source of aggregate fluctuations. 


\section{References}

Ball, Laurence and N. Gregory Mankiw, "The NAIRU in Theory and Practice," Journal of Economic Perspectives 16 (Fall 2002), 115-136.

Basu, Susanto, John Fernald, and Miles Kimball, "Are Technology Improvements Contractionary?" International Finance Discussion Paper 625 (Washington: Federal Reserve Board, September 1998).

Blanchard, Olivier Jean and Charles M. Kahn, "The Solution of Linear Difference Models Under Rational Expectations," Econometrica 48 (July 1980), 1305-1311.

Calvo, Guillermo A., "Staggered Prices in a Utility-Maximizing Framework," Journal of Monetary Economics 12 (September 1983), 383-398.

Clarida, Richard, Jordi Gali, and Mark Gertler, "The Science of Monetary Policy: A New Keynesian Perspective," Journal of Economic Literature 37 (December 1999), 16611707.

Clarida, Richard, Jordi Gali, and Mark Gertler, "Monetary Policy Rules and Macroeconomic Stability: Evidence and Some Theory," Quarterly Journal of Economics 115 (February 2000), 147-180.

Cooley, Thomas F. and Gary D. Hansen, "The Inflation Tax in a Real Business Cycle Model," American Economic Review 79 (September 1989), 733-748.

Driscoll, John C., "On the Microfoundations of Aggregate Demand and Aggregate Supply," Manuscript (Providence: Brown University, October 2000).

Francis, Neville and Valerie A. Ramey, "Is the Technology-Driven Real Business Cycle Hypothesis Dead? Shocks and Aggregate Fluctuations Revisited," Manuscript (San 
Diego: University of California at San Diego, September 2003).

Fuhrer, Jeffrey C. and George R. Moore, "Monetary Policy Trade-offs and the Correlation between Nominal Interest Rates and Real Output," American Economic Review 85 (March 1995), 219-239.

Gali, Jordi, "Technology, Employment, and the Business Cycle: Do Technology Shocks Explain Aggregate Fluctuations?" American Economic Review 89 (March 1999), 249271.

Gali, Jordi, "New Perspectives on Monetary Policy, Inflation, and the Business Cycle," Working Paper 8767 (Cambridge: National Bureau of Economic Research, February 2002).

Gali, Jordi and Mark Gertler, "Inflation Dynamics: A Structural Econometric Analysis," Journal of Monetary Economics 44 (October 1999), 195-222.

Gali, Jordi, J. David Lopez-Salido, and Javier Valles, "Technology Shocks and Monetary Policy: Assessing the Fed's Performance," Journal of Monetary Economics 50 (May 2003), 723-743.

Hamilton, James D., Time Series Analysis (Princeton: Princeton University Press, 1994).

Ireland, Peter N., "Interest Rates, Inflation, and Federal Reserve Policy since 1980," Journal of Money, Credit, and Banking 32 (August 2000, Part 1), 417-434.

Ireland, Peter N., "Sticky-Price Models of the Business Cycle: Specification and Stability," Journal of Monetary Economics 47 (February 2001), 3-18.

Ireland, Peter N., "Money's Role in the Monetary Business Cycle," Manuscript (Chestnut Hill: Boston College, May 2002a). 
Ireland, Peter N., "Technology Shocks in the New Keynesian Model," Working Paper 536 (Chestnut Hill: Boston College, Department of Economics, August 2002b).

Kerr, William and Robert G. King, "Limits on Interest Rate Rules in the IS Model," Federal Reserve Bank of Richmond Economic Quarterly 82 (Spring 1996), 47-75.

Kim, Chang-Jin and Charles R. Nelson, "Has the U.S. Economy Become More Stable? A Bayesian Approach Based on a Markov-Switching Model of the Business Cycle," Review of Economics and Statistics 81 (November 1999), 608-616.

King, Robert G., Charles I. Plosser, and Sergio T. Rebelo, "Production, Growth and Business Cycles: I. The Basic Neoclassical Model," Journal of Monetary Economics 21 (January 1988), 195-232.

Klein, Paul, "Using the Generalized Schur Form to Solve a Multivariate Linear Rational Expectations Model," Journal of Economic Dynamics and Control 24 (September 2000), 1405-1423.

Kydland, Finn E. and Edward C. Prescott, "Time To Build and Aggregate Fluctuations," Econometrica 50 (November 1982), 1345-1370.

Long, John B., Jr. and Charles I. Plosser, "Real Business Cycles," Journal of Political Economy 91 (February 1983), 39-69.

McCallum, Bennett T., "Price Level Determinacy with an Interest Rate Policy Rule and Rational Expectations," Journal of Monetary Economics 8 (November 1981), 319-329.

McCallum, Bennett T. and Edward Nelson, "An Optimizing IS-LM Specification for Monetary Policy and Business Cycle Analysis," Journal of Money, Credit, and Banking 31 (August 1999, Part 1), 296-316. 
McConnell, Margaret M. and Gabriel Perez-Quiros, "Output Fluctuations in the United States: What Has Changed Since the Early 1980's?" American Economic Review 90 (December 2000), 1464-1476.

Parkin, Michael. "A Comparison of Alternative Techniques of Monetary Control Under Rational Expectations." Manchester School of Economic and Social Studies 46 (September 1978): 252-287.

Rotemberg, Julio J., "Sticky Prices in the United States," Journal of Political Economy 90 (December 1982), 1187-1211.

Smets, Frank and Raf Wouters, "An Estimated Dynamic Stochastic General Equilibrium Model of the Euro Area," Journal of the European Economic Association 1 (September 2003), 1123-1175.

Steinsson, Jon, "Optimal Monetary Policy in an Economy with Inflation Persistence," Journal of Monetary Economics 50 (October 2003), 1425-1456.

Stock, James H. and Mark W. Watson, "Has the Business Cycle Changed and Why?" NBER Macroeconomics Annual 2002 (Cambridge: MIT Press, 2003), 159-218.

Taylor, John B., "Discretion Versus Policy Rules in Practice," Carnegie-Rochester Conference Series on Public Policy 39 (December 1993), 195-214.

Weil, Philippe, "The Equity Premium Puzzle and the Risk-Free Rate Puzzle," Journal of Monetary Economics 24 (November 1989), 401-421.

Woodford, Michael. Interest and Prices: Foundations of a Theory of Monetary Policy (Princeton: Princeton University Press, 2003). 
Table 1. Maximum Likelihood Estimates and Standard Errors

Standard

$\begin{array}{ccc}\text { Parameter } & \text { Estimate } & \text { Error } \\ \omega & 0.0617 & 0.0634 \\ \alpha_{x} & 0.0836 & 0.1139 \\ \alpha_{\pi} & 0.0000 & 0.0737 \\ \rho_{\pi} & 0.3597 & 0.0469 \\ \rho_{g} & 0.2536 & 0.0391 \\ \rho_{x} & 0.0347 & 0.0152 \\ \rho_{a} & 0.9470 & 0.0250 \\ \rho_{e} & 0.9625 & 0.0248 \\ \sigma_{a} & 0.0405 & 0.0157 \\ \sigma_{e} & 0.0012 & 0.0003 \\ \sigma_{z} & 0.0109 & 0.0028 \\ \sigma_{r} & 0.0031 & 0.0003\end{array}$


Table 2. Forecast Error Variance Decompositions

\section{Output Growth}

$\begin{array}{ccccc}\begin{array}{c}\text { Quarters } \\ \text { Ahead }\end{array} & \begin{array}{c}\text { Preference } \\ \text { Shock }\end{array} & \begin{array}{c}\text { Cost-Push } \\ \text { Shock }\end{array} & \begin{array}{c}\text { Technology } \\ \text { Shock }\end{array} & \begin{array}{c}\text { Policy } \\ \text { Shock }\end{array} \\ 1 & 25.6 & 6.6 & 27.5 & 40.3 \\ 4 & 22.2 & 13.7 & 26.3 & 37.8 \\ 8 & 22.1 & 13.8 & 26.3 & 37.8 \\ 12 & 22.1 & 13.9 & 26.3 & 37.7 \\ 20 & 22.0 & 14.2 & 26.2 & 37.6 \\ 40 & 22.0 & 14.5 & 26.1 & 37.4 \\ \infty & 21.9 & 14.6 & 26.1 & 37.4\end{array}$

\section{Inflation}

$\begin{array}{ccccc}\begin{array}{c}\text { Quarters } \\ \text { Ahead }\end{array} & \begin{array}{c}\text { Preference } \\ \text { Shock }\end{array} & \begin{array}{c}\text { Cost-Push } \\ \text { Shock }\end{array} & \begin{array}{c}\text { Technology } \\ \text { Shock }\end{array} & \begin{array}{c}\text { Policy } \\ \text { Shock }\end{array} \\ 1 & 2.3 & 61.6 & 15.9 & 20.3 \\ 4 & 1.8 & 64.3 & 14.9 & 19.0 \\ 8 & 1.7 & 66.4 & 14.0 & 17.9 \\ 12 & 1.7 & 67.3 & 13.6 & 17.4 \\ 20 & 1.7 & 68.1 & 13.3 & 16.9 \\ 40 & 1.7 & 68.8 & 12.9 & 16.5 \\ \infty & 1.7 & 69.0 & 12.9 & 16.4\end{array}$




\section{Interest Rate}

$\begin{array}{ccccc}\begin{array}{c}\text { Quarters } \\ \text { Ahead }\end{array} & \begin{array}{c}\text { Preference } \\ \text { Shock }\end{array} & \begin{array}{c}\text { Cost-Push } \\ \text { Shock }\end{array} & \begin{array}{c}\text { Technology } \\ \text { Shock }\end{array} & \begin{array}{c}\text { Policy } \\ \text { Shock }\end{array} \\ 1 & 76.1 & 9.1 & 6.5 & 8.3 \\ 4 & 78.8 & 15.8 & 2.4 & 3.0 \\ 8 & 76.7 & 20.2 & 1.4 & 1.7 \\ 12 & 75.0 & 22.6 & 1.0 & 1.3 \\ 20 & 72.9 & 25.3 & 0.8 & 1.1 \\ 40 & 70.5 & 27.8 & 0.7 & 0.9 \\ \infty & 69.7 & 28.7 & 0.7 & 0.9\end{array}$

\section{Output Gap}

$\begin{array}{ccccc}\begin{array}{c}\text { Quarters } \\ \text { Ahead }\end{array} & \begin{array}{c}\text { Preference } \\ \text { Shock }\end{array} & \begin{array}{c}\text { Cost-Push } \\ \text { Shock }\end{array} & \begin{array}{c}\text { Technology } \\ \text { Shock }\end{array} & \begin{array}{c}\text { Policy } \\ \text { Shock }\end{array} \\ 1 & 7.7 & 7.8 & 37.1 & 47.4 \\ 4 & 4.3 & 47.6 & 21.1 & 27.0 \\ 8 & 2.2 & 72.9 & 10.9 & 14.0 \\ 12 & 1.5 & 81.3 & 7.6 & 9.7 \\ 20 & 1.1 & 86.8 & 5.3 & 6.8 \\ 40 & 0.8 & 89.7 & 4.2 & 5.3 \\ \infty & 0.8 & 89.7 & 4.2 & 5.3\end{array}$

Note: Entries decompose the forecast error variance in each variable at each forecast horizon into percentages due to each shock. 
Table 3. Subsample Estimates and Standard Errors

$\begin{array}{ccccc}\text { Parameter } & \begin{array}{c}\text { Pre-1980 } \\ \text { Estimate }\end{array} & \begin{array}{c}\text { Standard } \\ \text { Error }\end{array} & \begin{array}{c}\text { Post-1980 } \\ \text { Estimate }\end{array} & \begin{array}{c}\text { Standard } \\ \text { Error }\end{array} \\ \omega & 0.0000 & 0.0115 & 0.0581 & 0.0693 \\ \alpha_{x} & 0.2028 & 0.0704 & 0.0000 & 0.0213 \\ \alpha_{\pi} & 0.0000 & 0.1092 & 0.0000 & 0.0154 \\ \rho_{\pi} & 0.3053 & 0.0591 & 0.3866 & 0.2526 \\ \rho_{g} & 0.2365 & 0.0601 & 0.3960 & 0.0615 \\ \rho_{x} & 0.0000 & 0.0068 & 0.1654 & 0.1136 \\ \rho_{a} & 0.9910 & 0.0112 & 0.9048 & 0.0583 \\ \rho_{e} & 0.5439 & 0.0061 & 0.9907 & 0.0133 \\ \sigma_{a} & 0.1538 & 0.1839 & 0.0302 & 0.0157 \\ \sigma_{e} & 0.0035 & 0.0004 & 0.0002 & 0.0002 \\ \sigma_{z} & 0.0104 & 0.0016 & 0.0089 & 0.0013 \\ \sigma_{r} & 0.0033 & 0.0007 & 0.0028 & 0.0004 \\ & & & & \end{array}$


Table 4. Forecast Error Variance Decompositions: Pre-1980 Subsample

Output Growth

$\begin{array}{ccccc}\begin{array}{c}\text { Quarters } \\ \text { Ahead }\end{array} & \begin{array}{c}\text { Preference } \\ \text { Shock }\end{array} & \begin{array}{c}\text { Cost-Push } \\ \text { Shock }\end{array} & \begin{array}{c}\text { Technology } \\ \text { Shock }\end{array} & \begin{array}{c}\text { Policy } \\ \text { Shock }\end{array} \\ 1 & 10.3 & 15.0 & 12.5 & 62.3 \\ 4 & 9.9 & 16.2 & 14.1 & 59.8 \\ 8 & 9.7 & 17.7 & 14.3 & 58.4 \\ 12 & 9.6 & 17.9 & 14.2 & 58.2 \\ 20 & 9.6 & 17.9 & 14.2 & 58.2 \\ 40 & 9.6 & 17.9 & 14.2 & 58.2 \\ \infty & 9.6 & 17.9 & 14.2 & 58.2\end{array}$

\section{Inflation}

$\begin{array}{ccccc}\begin{array}{c}\text { Quarters } \\ \text { Ahead }\end{array} & \begin{array}{c}\text { Preference } \\ \text { Shock }\end{array} & \begin{array}{c}\text { Cost-Push } \\ \text { Shock }\end{array} & \begin{array}{c}\text { Technology } \\ \text { Shock }\end{array} & \begin{array}{c}\text { Policy } \\ \text { Shock }\end{array} \\ 1 & 4.9 & 46.8 & 16.9 & 31.4 \\ 4 & 6.0 & 33.5 & 21.2 & 39.3 \\ 8 & 5.9 & 34.5 & 20.9 & 38.7 \\ 12 & 5.8 & 34.7 & 20.8 & 38.6 \\ 20 & 5.8 & 34.7 & 20.8 & 38.6 \\ 40 & 5.9 & 34.7 & 20.8 & 38.6 \\ \infty & 5.9 & 34.7 & 20.8 & 38.6\end{array}$




\section{Interest Rate}

$\begin{array}{ccccc}\begin{array}{c}\text { Quarters } \\ \text { Ahead }\end{array} & \begin{array}{c}\text { Preference } \\ \text { Shock }\end{array} & \begin{array}{c}\text { Cost-Push } \\ \text { Shock }\end{array} & \begin{array}{c}\text { Technology } \\ \text { Shock }\end{array} & \begin{array}{c}\text { Policy } \\ \text { Shock }\end{array} \\ 1 & 91.2 & 2.5 & 2.2 & 4.1 \\ 4 & 95.4 & 0.9 & 1.3 & 2.4 \\ 8 & 97.1 & 0.8 & 0.8 & 1.4 \\ 12 & 97.9 & 0.6 & 0.5 & 1.0 \\ 20 & 98.6 & 0.4 & 0.4 & 0.6 \\ 40 & 99.2 & 0.2 & 0.2 & 0.4 \\ \infty & 99.6 & 0.1 & 0.1 & 0.2\end{array}$

\section{Output Gap}

$\begin{array}{ccccc}\begin{array}{c}\text { Quarters } \\ \text { Ahead }\end{array} & \begin{array}{c}\text { Preference } \\ \text { Shock }\end{array} & \begin{array}{c}\text { Cost-Push } \\ \text { Shock }\end{array} & \begin{array}{c}\text { Technology } \\ \text { Shock }\end{array} & \begin{array}{c}\text { Policy } \\ \text { Shock }\end{array} \\ 1 & 8.5 & 12.4 & 27.7 & 51.4 \\ 4 & 6.9 & 29.3 & 22.4 & 41.5 \\ 8 & 6.4 & 33.5 & 21.0 & 39.0 \\ 12 & 6.4 & 33.8 & 20.9 & 38.9 \\ 20 & 6.4 & 33.8 & 20.9 & 38.8 \\ 40 & 6.4 & 33.8 & 20.9 & 38.8 \\ \infty & 6.4 & 33.8 & 20.9 & 38.8\end{array}$

Note: Entries decompose the forecast error variance in each variable at each forecast horizon into percentages due to each shock. 
Table 5. Forecast Error Variance Decompositions: Post-1980 Subsample Output Growth

$\begin{array}{ccccc}\begin{array}{c}\text { Quarters } \\ \text { Ahead }\end{array} & \begin{array}{c}\text { Preference } \\ \text { Shock }\end{array} & \begin{array}{c}\text { Cost-Push } \\ \text { Shock }\end{array} & \begin{array}{c}\text { Technology } \\ \text { Shock }\end{array} & \begin{array}{c}\text { Policy } \\ \text { Shock }\end{array} \\ 1 & 31.9 & 0.0 & 43.9 & 24.2 \\ 4 & 30.3 & 1.6 & 43.6 & 24.5 \\ 8 & 30.3 & 1.7 & 43.5 & 24.5 \\ 12 & 30.3 & 1.7 & 43.5 & 24.5 \\ 20 & 30.3 & 1.7 & 43.5 & 24.5 \\ 40 & 30.3 & 1.7 & 43.5 & 24.5 \\ \infty & 30.3 & 1.7 & 43.5 & 24.5\end{array}$

\section{Inflation}

$\begin{array}{ccccc}\begin{array}{c}\text { Quarters } \\ \text { Ahead }\end{array} & \begin{array}{c}\text { Preference } \\ \text { Shock }\end{array} & \begin{array}{c}\text { Cost-Push } \\ \text { Shock }\end{array} & \begin{array}{c}\text { Technology } \\ \text { Shock }\end{array} & \begin{array}{c}\text { Policy } \\ \text { Shock }\end{array} \\ 1 & 2.8 & 49.1 & 29.5 & 18.6 \\ 4 & 1.5 & 61.4 & 22.8 & 14.4 \\ 8 & 1.5 & 69.8 & 17.6 & 11.1 \\ 12 & 1.6 & 74.5 & 14.7 & 9.3 \\ 20 & 1.4 & 80.0 & 11.4 & 7.2 \\ 40 & 1.0 & 85.9 & 8.0 & 5.1 \\ \infty & 0.6 & 91.5 & 4.8 & 3.1\end{array}$




\section{Interest Rate}

$\begin{array}{ccccc}\begin{array}{c}\text { Quarters } \\ \text { Ahead }\end{array} & \begin{array}{c}\text { Preference } \\ \text { Shock }\end{array} & \begin{array}{c}\text { Cost-Push } \\ \text { Shock }\end{array} & \begin{array}{c}\text { Technology } \\ \text { Shock }\end{array} & \begin{array}{c}\text { Policy } \\ \text { Shock }\end{array} \\ 1 & 80.5 & 7.2 & 7.5 & 4.8 \\ 4 & 81.1 & 12.6 & 3.9 & 2.4 \\ 8 & 77.4 & 18.5 & 2.5 & 1.6 \\ 12 & 73.0 & 23.6 & 2.0 & 1.3 \\ 20 & 65.2 & 32.1 & 1.7 & 1.0 \\ 40 & 52.8 & 45.1 & 1.3 & 0.8 \\ \infty & 36.9 & 61.6 & 0.9 & 0.6\end{array}$

\section{Output Gap}

$\begin{array}{ccccc}\begin{array}{c}\text { Quarters } \\ \text { Ahead }\end{array} & \begin{array}{c}\text { Preference } \\ \text { Shock }\end{array} & \begin{array}{c}\text { Cost-Push } \\ \text { Shock }\end{array} & \begin{array}{c}\text { Technology } \\ \text { Shock }\end{array} & \begin{array}{c}\text { Policy } \\ \text { Shock }\end{array} \\ 1 & 13.5 & 0.0 & 53.0 & 33.5 \\ 4 & 11.6 & 7.3 & 49.7 & 31.4 \\ 8 & 9.2 & 24.3 & 40.8 & 25.8 \\ 12 & 7.6 & 37.4 & 33.7 & 21.3 \\ 20 & 5.8 & 52.7 & 25.4 & 16.1 \\ 40 & 3.9 & 68.0 & 17.2 & 10.9 \\ \infty & 3.9 & 68.0 & 17.2 & 10.9\end{array}$

Note: Entries decompose the forecast error variance in each variable at each forecast horizon into percentages due to each shock. 

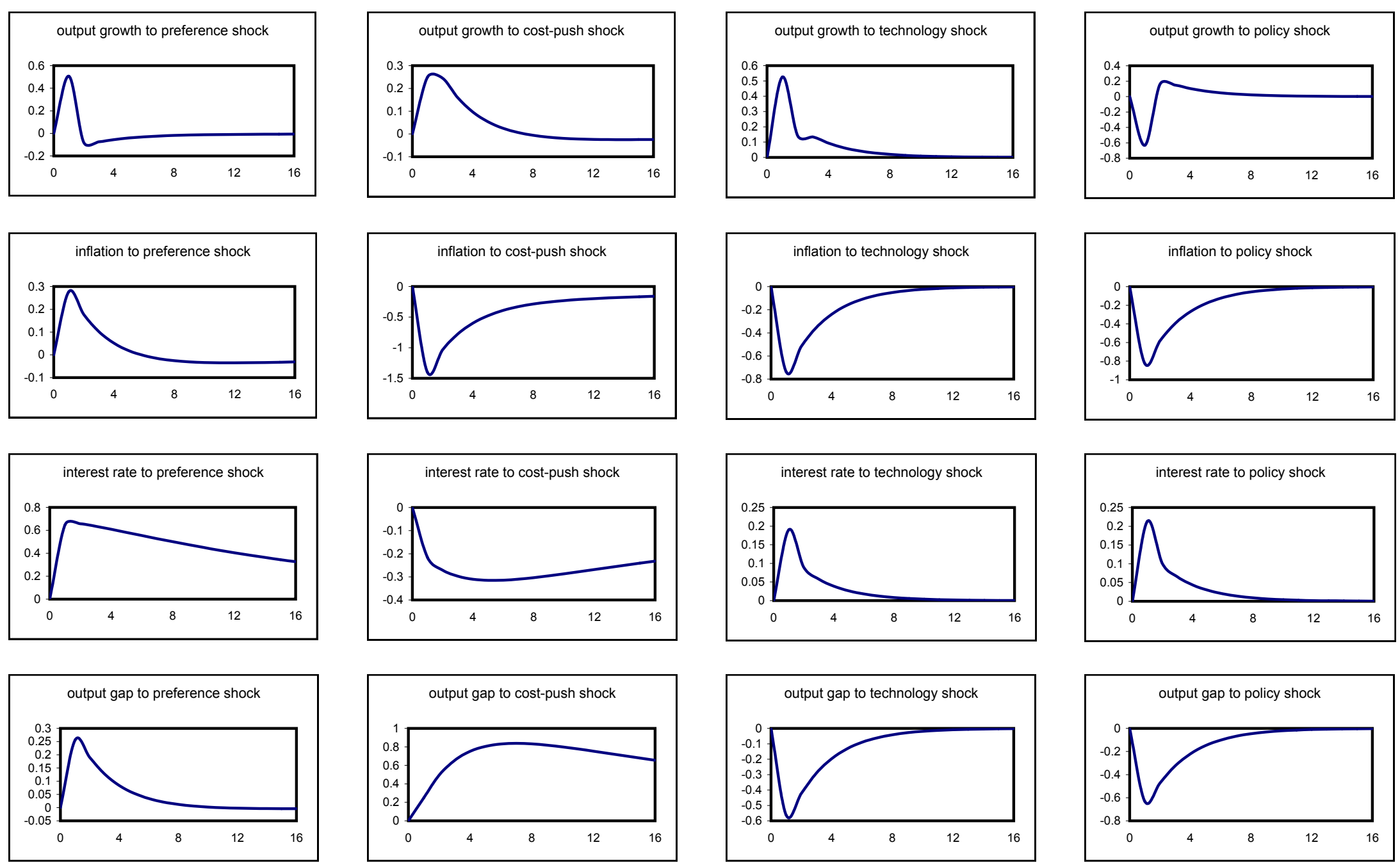

Figure 1. Impulse Responses.

Each panel shows the percentage-point response of one of the model's variables to a one-standard-deviation shock.

The inflation and interest rates are expressed in annualized terms. 

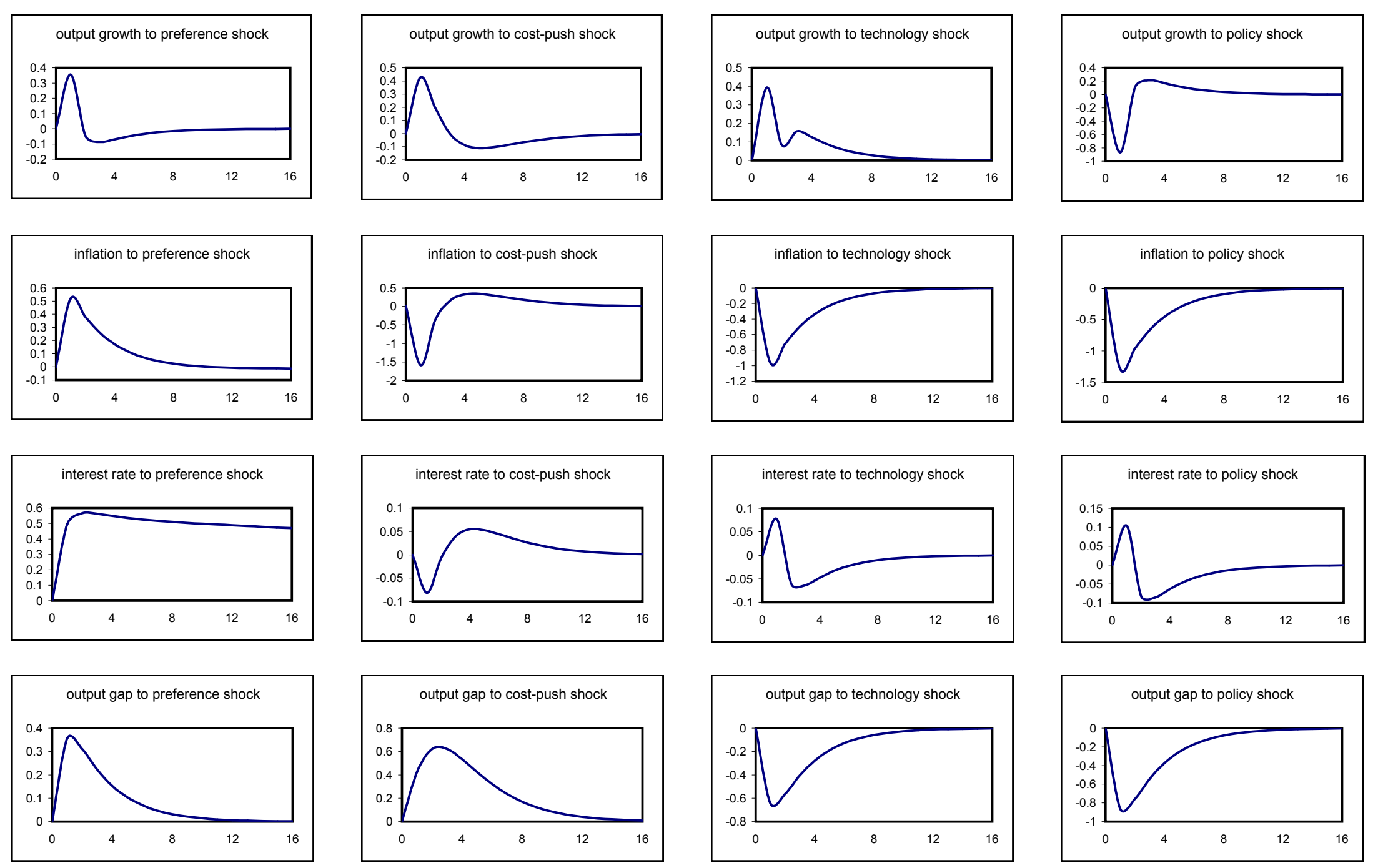

Figure 2. Impulse Responses: Pre-1980 Subsample.

Each panel shows the percentage-point response of one of the model's variables to a one-standard-deviation shock.

The inflation and interest rates are expressed in annualized terms. 

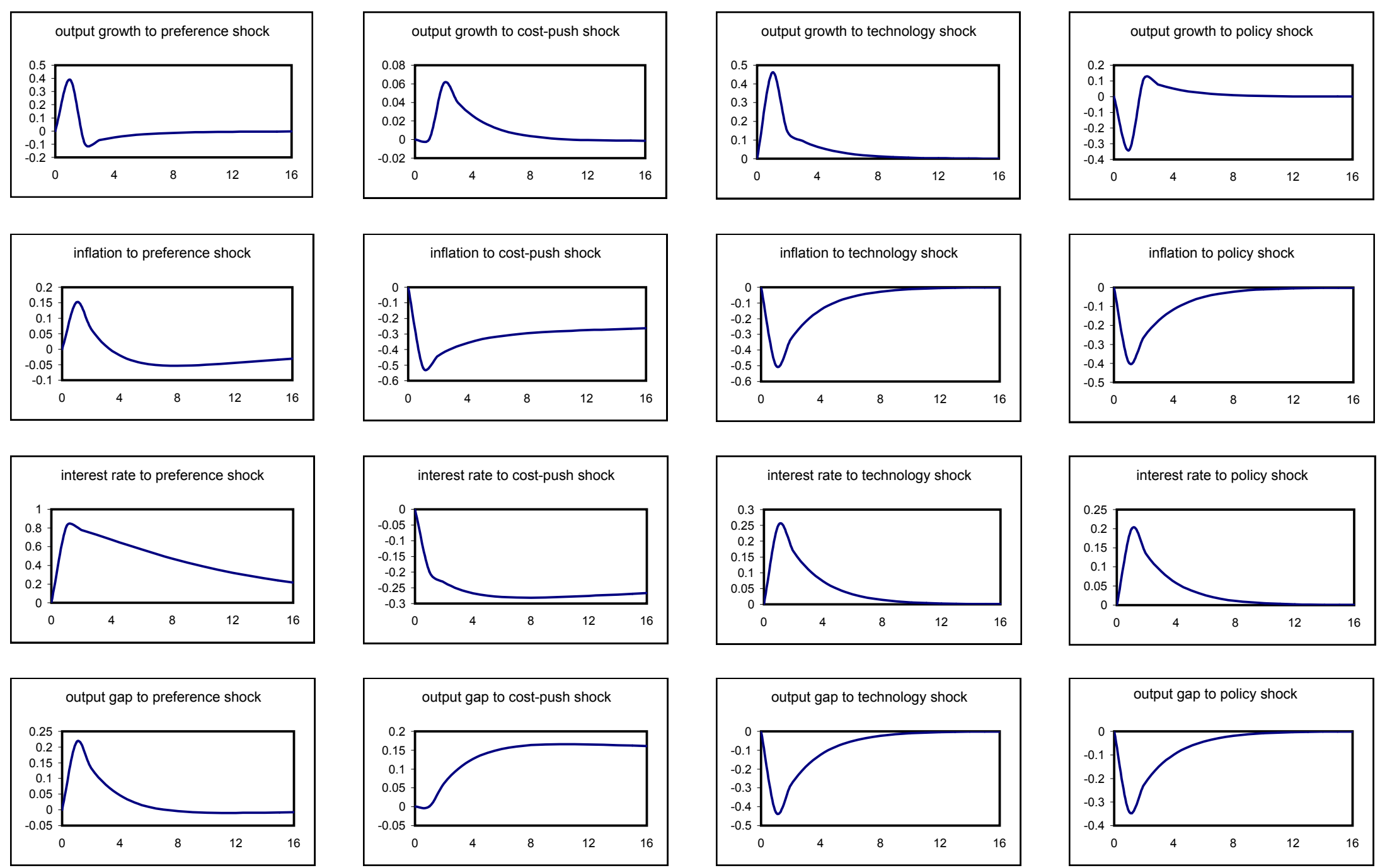

Figure 3. Impulse Responses: Post-1980 Subsample.

Each panel shows the percentage-point response of one of the model's variables to a one-standard-deviation shock.

The inflation and interest rates are expressed in annualized terms. 